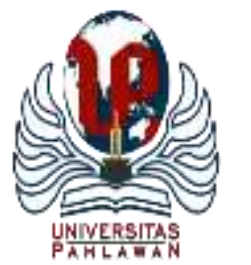

Edukatif : Jurnal Ilmu Pendidikan Volume 3 Nomor 6 Tahun 2021 Halm 4889 - 4903

EDUKATIF: JURNAL ILMU PENDIDIKAN

Research \& Learning in Education

https://edukatif.org/index.php/edukatif/index

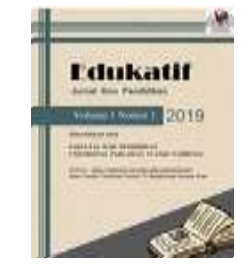

\title{
Pengembangan Bahan Ajar Membaca Berbasis Higher Order Thinking Skills pada Siswa Sekolah Dasar
}

\author{
Febrina Dafit ${ }^{1 凶}$, Dea Mustika ${ }^{2}$ \\ Universitas Islam Riau, Indonesia ${ }^{1,2}$ \\ E-mail : febrinadafit@gmail.com ${ }^{1}$, deamustika@edu.uir.ac.id ${ }^{2}$
}

\begin{abstract}
Abstrak
Bahan ajar merupakan segala bentuk bahan baik itu informasi, alat, maupun teks yang digunakan dalam proses pembelajaran. Penelitian ini bertujuan untuk melakukan pengembangan e-modul membaca berbasis HOTS. Penelitian ini menggunakan metode R\&D yang mengadopsi model ADDIE yang disederhanakan menjadi empat tahapan yaitu (Analysis, Design, Development, Impementasi). Instrumen pengumpulan data yang digunakan berupa angket yang diberikan kepada validator desain, materi validator, validator bahasa untuk kelayakan, serta respon guru dan siswa untuk menguji kemenarikan. Hasil dari penelitian ini, menghasilkan produk e-modul membaca berbasis HOTS yang dapat digunakan pada jenjang SD sebagai bahan ajar atau pegangan buku ajar siswa yang telah memenuhi kriteria sangat baik dengan skor rata-rata dari validator desain 96,99\% validator materi $96,7 \%$ dan validator bahasa 96,3\% dengan kategori sangat layak serta respon yang diberikan oleh pendidik 90,5\% dengan kategori sangat menarik, dan dilakukan coba skala kecil 92,5\% dengan kategori sangat menarik. Bahan ajar e-modul membaca berbasis HOTS sudah layak digunakan dalam proses pembelajaran.
\end{abstract}

Kata Kunci: Bahan Ajar, E-Modul, HOTS.

\begin{abstract}
Teaching materials are all forms of materials, both information, tools, and texts used in the learning process. This study aims to develop a HOTS-based reading e-module. This study uses the R\&D method which adopts the ADDIE model which is simplified into four stages (Analysis, Design, Development, Implementation). The data collection instruments used were in the form of a questionnaire given to the design validator, material validator, language validator for feasibility, and teacher and student responses to test attractiveness. The results of this study, produce a HOTS-based reading e-module product that can be used at the elementary level as teaching materials or student textbooks that have met the criteria very well with an average score of $96.99 \%$ design validator material validator $96.7 \%$ and language validator $96.3 \%$ with a very decent category and the response given by educators $90.5 \%$ with a very interesting category, and a small scale trial of $92.5 \%$ with a very interesting category. HOTS-based reading e-module teaching materials are suitable for use in the learning process.
\end{abstract}

Keywords: Teaching Materials, E-Modules, HOTS.

Copyright (c) 2021 Aulia Diana Devi, Subiyantoro

$\triangle$ Corresponding author

Email : 19204090026@student.uin-suka.ac.id

DOI : https://doi.org/10.31004/edukatif.v3i6.1565

ISSN 2656-8063 (Media Cetak)

ISSN 2656-8071 (Media Online)

Edukatif : Jurnal Ilmu Pendidikan Vol 3 No 6 Tahun 2021 p-ISSN 2656-8063 e-ISSN 2656-8071 
4890 Pengembangan Bahan Ajar Membaca Berbasis Higher Order Thinking Skills pada Siswa Sekolah DasarAulia Diana Devi, Subiyantoro

DOI: https://doi.org/10.31004/edukatif.v3i6.1565

\section{PENDAHULUAN}

Pendidikan merupakan suatu usaha sadar dan terencana untuk mewujudkan suasana belajar dan proses pembelajaran agar peserta didik secara aktif mengembangkan potensi yang ada dalam dirinya untuk memiliki kekuatan spiritual keagamaan, pengendalian diri, kepribadian yang baik, kecerdasan, akhlak yang mulia, serta keterampilan yang diperlukan dirinya, masyarakat, bangsa dan negara. Melalui pendidikan diharapkan dapat mengembangkan potensi peserta didik sehingga mampu menjadi sumber daya manusia yang lebih berkualitas (Tania, 2017). Untuk mewujudkan potensi peserta didik, guru memilki peranan yang sangat penting dalam proses pembelajaran. Tujuan pengajaran akan dicapai apabila peserta didik berusaha secara aktif untuk mencapainya (Pane \& Dasopang, 2017).

Pelaksanaan kegiatan pembelajaran tidak terlepas dari penggunaan bahan ajar. Bahan ajar merupakan segala bahan (baik itu informasi, alat, maupun teks) yang disusun secara sistematis yang menampilkan sosok utuh dari kompetensi yang akan dikuasai peserta didik dan digunakan dalam proses pembelajaran dengan tujuan untuk merencanakan dan penelaahan implementasi pembelajaran. Bentuknya bermacam-macam, seperti: buku pelajaran, modul, handout, LKS, model atau maket, bahan ajar audio, dan bahan ajar interaktif. Menurut (Simarmata et al., 2017) berkembangnya teknologi mendorong terjadinya perpaduan antara teknologi cetak dengan teknologi komputer dalam kegiatan pembelajaran yang disebut dengan e-book yang dirancang semenarik mungkin. Berbagai bahan ajar cetak, salah satunya yaitu modul dapat ditransformasikan penyajiannya ke dalam bentuk elektronik, sehingga melahirkan suatu istilah modul elektronik atau yang biasa dikenal dengan istilah e-modul. Istilah elektronik modul merupakan penggabungan istilah modul dalam bentuk bahan ajar elektronik (e-book). Selain itu menurut (Laili et al., 2019) modul elektronik adalah sumber belajar yang berisikan materi, metode, batasan-batasan dan cara mengevaluasi yang dirancang secara sistematis dan menarik perhatian peserta didik untuk mencapai kompetensi sesuai dengan kurikulum secara elektronik. Sedangkan menurut Gunadharma (Sugianto et al., 2013) yaitu modul elektronik juga dapat digunakan dimana saja, sehingga lebih praktis untuk dibawa kemana saja. Karena merupakan penggabungan dari media cetak dan komputer, maka modul elektronik dapat menyajikan informasi secara terstruktur, menarik serta memiliki tingkat interaktifitas yang tinggi. E-modul dapat menampilkan teks, gambar, animasi, dan video melalui piranti elektronik berupa computer (Shobrina et al., 2020). Jenis bahan ajar seperti modul ini bisa melatih siswa dalam membaca.

Membaca adalah keterampilan yang harus dikuasai, khususnya bagi siswa SD di dalam memahami proses pembelajaran karena dengan membaca proses mendapatkan informasi dapat terbentuk dengan baik. Menurut (Irdawati, Yunidar dan Darmawan, 2017) membaca adalah "sesuatu yang rumit yang melibatkan banyak hal dan tidak hanya sekedar melafalkan tulisan, tetapi juga melibatkan aktivitas visual yaitu proses menterjemahkan simbol tulisan (huruf) ke dalam kata-kata lisan".

Pembelajaran keterampilan membaca tidak hanya diharapkan siswa mampu membaca, tetapi dengan membaca siswa diharapkan mampu memahami dan kritis terhadap bacaan yang dibaca. Sejalan dengan hal itu (Character \& Comprehension, 2012) menyatakan bahwa "pembelajaran membaca hendaknya diarahkan agar siswa menikmati kegiatan membaca, mampu membaca dalam hati dengan kecepatan yang fleksibel, dan memperoleh tingkat pemahaman yang cukup atas isi bacaan". Selain itu, hendaknya pembelajaran membaca pada siswa mampu membentuk karakter positif, diantaranya teliti, memiliki rasa ingin tahu, kreatif, kegemaran, dan hal-hal positif lainnya dengan membaca. Dengan keterampilan membaca dan menulis, seseorang dapat mengerti berbagai macam informasi yang terkandung dalam tulisan secara benar (Saonah, 2018).

Menurut (Elvina, 2018) hal yang terpenting dari membaca adalah sebuah pemahaman yang artinya tidak akan memiliki hasil apapun apabila seseorang yang membaca kalau tidak memiliki pemahaman dari apa yang dibacanya. Oleh sebab itu salah satu tujuan membaca adalah memberikan informasi atau 
4891 Pengembangan Bahan Ajar Membaca Berbasis Higher Order Thinking Skills pada Siswa Sekolah DasarAulia Diana Devi, Subiyantoro

DOI: https://doi.org/10.31004/edukatif.v3i6.1565

pengetahuan berdasarkan pemahaman atas isi bacaan yang telah dibaca oleh siswa. Informasi-informasi atau pengetahuan yang diperloeh siswa dari bacaan merupakan informasi atau pengetahuan yang sudah diketahuinya maupun yang bersifat baru.

Unsur yang harus ada dalam pembelajaran membaca adalah pemahaman, karena kegiatan membaca yang tidak disertai dengan pemahaman belum disebut kegiatan membaca. Kemampuan yang harus dimiliki apabila seseorang memahami bacaan (Astuti, 2012) adalah sebagai berikut: “(1) kemampuan menangkap arti kata dan ungkapan yang digunakan penulis, (2) kemampuan menangkap makna tersurat dan tersirat, (3) kemampuan membuat kesimpulan".

Indikator keberhasilan siswa dalam pembelajaran membaca adalah proses pemahaman yang telah dilakukan siswa dalam kegiatan membaca. Siswa akan mudah memahami makna bacaan apabila siswa mampu memahami teks bacaan yang telah dibaca, baik makna tersirat maupun makna tersurat. Tidak hanya itu, salah satu indikator jika siswa mampu memahami bacaan adalah siswa mampu menceritakan kembali isi bacaan yang telah dibaca, menceritakannya baik secara tulis maupun secara lisan.

Kegiatan pemahaman siswa terhadap bacaan yang telah dibacanya merupakan salah satu kemampuan literasi yang harus dikuasai oleh siswa, khususnya siswa Sekolah Dasar. Kegiatan literasi adalah kegiatan wajib untuk diintegrasikan di dalam kegiatan kelas. Literasi adalah kata kunci bagi manusia untuk memahami dan mengatasi tantangan masa kini yaitu revolusi industri (Rahman \& Atjalau, 2019).

Dalam lingkup akademik di sekolah dasar, keterampilan membaca penting untuk dikuasai oleh siswa. Membaca kritis penting dikuasai leh siswa sekolah dasar sebagai wujud atau bentuk dari kegitan literasi yang sangat penting untuk diterapkan di sekolah dasar (Rahman \& Atjalau, 2019). Literasi juga merupakan element penting yang sesuai dengan perkembangan revolusi industri 4.0 saat ini (Rahman \& Atjalau, 2019). Kegiatan literasi di sekolah dasar bisa diterapkan dengan kegiatan membaca pemahaman. Dengan membaca pemahaman diharapkan siswa akan mampu berpikir tingkat tinggi atau lebih dikenal dengan istilah High Order Thinking Skill (HOTS). Pembelajaran HOTS adalah pembelajaran berorientasi pada keterampilan berpikir tingkat tinggi yang mengajak peserta didik untuk berpikir kritis, kreatif, kolaborasi, dan komunik (Retnoasih, 2018).

Proses membaca mengharuskan siswa untuk berkognisi tingkat tinggi, yang mana menuntut siswa untuk bijaksana, penuh tenggang hati, berpikir mendalam, evaluatif, serta analitis. Kegiatan meningkatkan kemampuan membaca siswa termasuk pada upaya pemenuhan tuntutan pendidikan di abad 21 untuk menciptakan generasi yang mampu berpikir tingkat tinggi (Higher Order Thinking). Pendidikan di abad 21 adalah pendidikan yang mencerminkan empat hal diantaranya critical thinking and problem solving, creative and innovation, communication and collaboration (Sekarini, 2020). Penulis melakukan studi literatur pada beberapa artikel ilmiah salah satunya adalah artikel oleh (Anggia et al., 2018) yang menyatakan bahwa kegiatan membaca merupakan kegiatan yang mendukung kegiatan literasi sekolah yang bertujuan untuk menciptakan generasi yang literat karena menurut Progress in International Reading Literacy Study (PIRLS) 2006, Indonesia berada di peringkat bawah.

Namun pada kenyataannya kemampuan membaca pemahaman yang diharapkan pada siswa belum terlihat pada siswa SD saat ini. Informasi yang diperoleh dari guru kelas SD menyatakan bahwa siswa sangat kesulitan dalam memahami bacaan serta kesulitan dalam berpikir tingkat tinggi di dalam membaca. Hal ini terlihat ketika siswa diberikan pertanyaan berdasarkan teks bacaan yang telah dibaca, mereka belum mampu menjawab pertanyaan tersebut. Siswa mampu menjawab pertanyaan jika kembali membuka teks bacaan, artinya siswa belum bisa menjawab pertanyaan dengan kalimat sendiri. Selain itu, guru hanya menekankan proses membaca tanpa melihat apakah siswa memahami bacaan atau tidak, yang terpenting proses pembelajaran membaca selesai.

Dilihat dari permasalahan di atas, siswa sangat kesulitan dalam memahami bacaan, maka dari itu penulis berupaya menghadirkan sebuah alternatif yang dirasa efektif dan inovatif dalam mengatasi hal 
4892 Pengembangan Bahan Ajar Membaca Berbasis Higher Order Thinking Skills pada Siswa Sekolah DasarAulia Diana Devi, Subiyantoro

DOI: https://doi.org/10.31004/edukatif.v3i6.1565

tersebut. Solusi yang dimaksud yaitu mengembangkan bahan ajar E-modul. Kelebihan e-modul dari bahan ajar cetak adalah lengkap dengan media interaktif seperti video, audio, animasi dan fitur interaktif lain yang dapat dimainkan dan diputar ulang oleh siswa saat menggunakan e-modul. E-modul ini dinilai bersifat inovatif karena dapat menampilkan bahan ajar yang lengkap, menarik, interaktif, dan mengemban fungsi kognitif yang bagus. Selain itu e-modul yang dikembangkan berbasis HOTS.

Berdasarkan uraian di atas, maka penulis akan melakukan penelitian pengembangan e-modul membaca berbasis High Order Thinking Skills (HOTS) yang digunakan siswa sekolah dasar, dengan harapan dapat membantu guru untuk mempermudah peserta didik belajar dimanapun mereka belajar dan dengan siapapun mereka.

\section{METODE}

Jenis penelitian yang akan digunakan peneliti adalah penelitian dan pengembangan (Research and Development). Menurut (Hanafi, 2017) penelitian ini merupakan upaya untuk mengembangkan ilmu pengetahuan dan mendapat temuan-temuan yang baru. Sedangkan menurut (Purnama, 2016) metode penelitian dan pengembangan (research and development) adalah metode penelitian yang digunakan untuk menghasilkan produk tertentu dan menguji keefektifannya. Penelitian ini di pilih karena peneliti mengembangkan produk berupa alat bantu pembelajaran. Penelitian dan pengembangan akan menghasilkan produk berupa e-modul membaca, kemudian dijadikan alternatif yang tentunya akan melalui tahap pengujian terlebih dahulu.

Dalam mengembangan e-modul membaca ini, peneliti menggunakan model ADDIE. Menurut Putra dkk, (Qondias et al., 2016) model desain pembelajaran yang sifatnya lebih generik yaitu model ADDIE (Analysis-Design-Delevop-Implement-Evaluate). Model ini merupakan salah satu model desain pembelajaran sistematik (Tegeh \& Kirna, 2013). Model ADDIE muncul pada tahun 1990-an yang dikembangkan oleh Reiser dan Mollena. Model ADDIE ada lima fase atau tahap yang perlu dilakukan secara sistematis dan sistem. Tahapan model ADDIE untuk mengembangkan e-modul membaca ini dimodifikasi menjadi empat tahapan yaitu analisis, design, development dan implementasi dan evaluasi. Penelitian ini dilakukan secaran daring (online) karena kondisi yang tidak memungkinkan untuk dating secara langsung ke Sekolah, hal ini terjadi karena penyebaran virus Corona-19 yang semakin memburuk. Teknik pengumpulan data ada tiga yaitu:

Angket kebutuhan dalam pengembangan produk ini akan dianalisis menggunakan deskriptif kualitatif dengan cara penyajian data melalui beberapa pertanyaan sesuai dengan keadaan dan kebutuhan yang ada pada saat penelitian tanpa adanya perhitungan didalamnya semua di jabarkan dalam bentuk deskriptif.

Angket validasi yang akan diberikan kepada ahli materi, bahasa, serta desain dan guru, pada penelitian dan pengembangan ini menggunakan skala Likert dan pengukuran yang merujuk pada buku karangan (Riduwan, 2016) Analisis kuantitatif merupakan pemberian soal yang akan di hasilkan skor dalam hal ini dapat dilihat pada rumus yang ada dibawah ini:

Rumus presentase yang digunakan, sebagai berikut:

$$
P=\frac{\Sigma \mathrm{X}}{\Sigma \mathrm{Xi}} \times 100 \%
$$

Keterangan:

$\mathrm{P} \quad$ : Presentase

$\sum \mathrm{x} \quad$ : Jumlah keseluruhan jawaban responden dalam seluruh item

$\sum x i \quad$ Jumlah keseluruhan skor ideal 
4893 Pengembangan Bahan Ajar Membaca Berbasis Higher Order Thinking Skills pada Siswa Sekolah DasarAulia Diana Devi, Subiyantoro

DOI: https://doi.org/10.31004/edukatif.v3i6.1565

Untuk menentukan kriteria dalam menentukan hasil dari validasi, sebagai berikut:

Tabel 1 Tingkat Kevalidan dan Revisi Produk

\begin{tabular}{cl}
\hline Persentase (\%) & \multicolumn{1}{c}{ Kriteria Valid } \\
\hline $76-100$ & Valid (tanpa revisi) \\
\hline $56-75$ & Cukup valid (tanpa revisi) \\
\hline $40-55$ & Kurang valid (revisi) \\
\hline $0-39$ & Tidak valid (revisi) \\
\hline & Sumber: (Listiawan, 2016)
\end{tabular}

Angket tanggapan digunakan untuk mengumpulkan data mengenai tanggapan peserta didik terhadap e-modul membaca yang dikembangkan dengan menggunakan Skala Guttman. Menurut (Riduwan, 2016) Skala Guttman merupakan skala yang digunakan untuk jawaban yang bersifat jelas (tegas) dan konsisten. Misalnya: Yakin-Tidak Yakin; Ya-Tidak; Benar-Salah; Positif-Negatif; Penah-Belum Pernah; Setuju-Tidak Setuju; dan lain sebagaianya. Untuk mengetahui posisi persentase jawaban "ya" yang diperoleh dari angket maka dihitung terlebih dahulu kemudian ditempatkan dalam rentang skala pesentase sebagai berikut:

$\begin{array}{ll}\text { Nilai Jawaban "ya" } & =1 \\ \text { Nilai Jawaban "Tidak" } & =0 \\ \text { Dikonversikan dalam pesentase : } & \\ \text { Jawaban "Ya": } 1 \text { X 100\% } & =100 \% \\ \text { Jawaban "Tidak" : } 0 \text { X } 100 \% & =0 \%\end{array}$

\section{HASIL DAN PEMBAHASAN PENELITIAN}

Pengembangan bahan ajar ini menggunakan model pengembangan ADDIE dengan lima tahapan yaitu Analysis, Design-Delevopment, Implementation, Evaluation (Define, models. Deskripsi data hasil penelitian dijelaskan sebagai berikut:

\section{Tahap Analysis (analisis)}

Tahap analisis dilakukan dengan analisis kurikulum, analisis guru, dan analisis siswa. Analisis dilakukan untuk mendapatkan informasi dalam proses pengembangan e-modul membaca berbasis Higher Order Thinking Skills (HOTS). Adapun analisis tersebut dipaparkan sebagai berikut:

\section{a. Analisis Kurikulum}

Analisis yang dilakukan adalah analisis terkait kompetensi inti, kompetensi dasar (KD) dan indikatorindikator pencapaian kompetensi yang mengacu pada kurikulum 2013. Analisis ini akan menjadi dasar materi dalam pengembangan e-modul membaca. Analisis kurikulum bertujuan untuk mengetahui cakupan materi, tujuan pembelajaran, dan pemilihan strategi yang sesuai sebagai landasan untuk mengembangkan e-modul membaca yang diharapkan. Tahapan analisis yang pertama adalah Kompetensi Inti yang bertujuan untuk melihat kompetensi yang harus dimiliki oleh siswa Sekolah Dasar. Kompetensi Inti harus menggambarkan kualitas yang seimbang antara pencapaian hard skills dan soft skills. Analisis berikutnya adalah analisis Kompetensi Dasar (KD).

\section{b. Analisis Guru}

Penelitian ini dikembangkan dari masalah yang muncul pada saat proses pembelajaran berlangsung. Berdasarkan hasil wawancara dengan guru, maka didapatkan informasi bahwa guru belum pernah membuat bahan ajar sendiri, sehingga siswa mengalami kendala dalam memahami materi. Terlebih lagi siswa tidak 
4894 Pengembangan Bahan Ajar Membaca Berbasis Higher Order Thinking Skills pada Siswa Sekolah DasarAulia Diana Devi, Subiyantoro

DOI: https://doi.org/10.31004/edukatif.v3i6.1565

dapat mengembangkan berpikir kritis dan kreatif sesuai dengan tuntutan Kompetensi Inti yang harus dicapai siswa SD.

Guru belum menginovasikan bahan ajar yang akan diajarkan ke siswa dengan tuntutan kurikulum. Seharusnya guru bisa menghadirkan sebuah bahan ajar yang kreatif, menarik, dan meningkatkan kemampuan berpikir kritis siswa untuk menghasilkan pembelajaran yang inovatif. Terlebih lagi dengan adanya wabah Covid-19 yang menyebabkan pembelajaran harus dilaksanakan secara daring. Guru harus bisa menjadi fasilitator agar tujuan pembelajaran dapat tercapai meskipun tidak melalui tatap muka dengan siswa. Maka dari itu peneliti berupaya menghadirkan alternatif untuk mengatasi permasalahan yang diamali oleh guru, solusi yang dirasa efektif yaitu mengembangkan bahan ajar membaca dalam bentuk e-modul yang berbasis HOTS.

\section{c. Analisis Siswa}

Permasalahan yang dialami siswa berkaitan dengan membaca adalah kesulitan dalam memahami bacaan serta kesulitan dalam berpikir tingkat tinggi. Hal ini terlihat ketika siswa diberikan pertanyaan berdasarkan teks bacaan yang telah dibaca, mereka belum mampu menjawab pertanyaan tersebut. Analisis siswa dilakukan melalui wawancara via telepon karena kondisi yang tidak memungkinkan untuk bertemu secara langsung. Wawancara yang dilakukan adalah wawancara tidak terstruktur, yaitu wawancara yang dilakukan tanpa menggunakan pedoman wawancara, melainkan berkembang berdasarkan jawaban responden. Artinya, pertanyaan baru dapat muncul berdasarkan jawaban responden sehingga mampu menggali informasi yang lebih dalam. Pada tahap analisis ini peneliti melakukan wawancara kepada guru untuk memperoleh informasi terkait karakteristik siswa dan hasil belajar yang diperoleh siswa. Selain itu peneliti juga melakukan wawancara kepada siswa untuk memperoleh informasi gambaran dalam membuat emodul membaca yang sesuai dengan apa yang diinginkan oleh siswa.

Berdasarkan analisis tersebut, terlihat bahwa diperlukan bahan ajar membaca yang dapat mengarahkan rasa ingin tahu siswa dan keaktifan siswa ke arah yang positif. Bahan ajar membaca yang digunakan hendaklah disesuaikan dengan karakteristik siswa. Demikian juga dalam penyajian pembelajaran, hendaknya disesuaikan dengan materi yang menjadi materi pokok pembejaran serta adanya soal-soal yang meningkatkan kemampuan berpikir tingkat tinggi siswa.

Sejalan dengan permasalahan di atas e-modul membaca berbasis Higher Order Thinking Skills (HOTS) pada tema 6 subtema 1 akan sangat tepat untuk di belajarkan di kelas. E-modul membaca berbasis Higher Order Thinking Skills (HOTS) bertujuan untuk melatih penalaran, mengembangkan aktivitas yang melibatkan imajinasi dalam memecahkan masalah dan membangun kemampuan menyampaikan informasi yang disampaikan pada e-modul ini. Di samping itu juga mampu mengembangkan kemampuan berpikir tingkat tinggi siswa, meningkatkan keaktifan siswa, melatih siswa untuk berpikir kritis, serta melatih siswa terbiasa menghadapi permasalahan yang ada di dalam materi.

\section{Tahap Design (Perancangan)}

E-modul membaca yang dirancang disesuaikan dengan KI, KD, dan tujuan pembelajaran berdasarkan analisis yang telah dilakukan. E-modul membaca yang dirancang mendorong siswa untuk dapat meningkatkan kemampuan pemahaman akan bacaan serta melatih, meningkatkan kemampuan berpikir tingkat tinggi, dan menambah pengetahuan tentang materi yang dipelajari. E-modul yang dirancang dilengkapi dengan warna-warna, gambar-gambar berwarna yang menarik bagi siswa. E-modul membaca berbasis Higher Order Thinking Skills (HOTS) terlihat pada soal-soal yang disajikan dalam e- modul yang diberikan tanda khusus untuk membedakan soal biasa dengan soal HOTS.

E-modul membaca berbasis Higher Order Thinking Skills (HOTS) dirancang pada microsoft office word kemudian di export ke bentuk PDF, dan selanjutnya di jadikan elektronik modul dengan bantuan 
4895 Pengembangan Bahan Ajar Membaca Berbasis Higher Order Thinking Skills pada Siswa Sekolah DasarAulia Diana Devi, Subiyantoro

DOI: https://doi.org/10.31004/edukatif.v3i6.1565

aplikasi flip PDF Profesional. Tahapan perancangan e-modul membaca disesuaikan dengan isi e-modul. Berikut ini adalah bagian isi e-modul:

\section{a. Cover (Sampul)}

Cover merupakan bagian sampul (depan dan belakang) dari e-modul yang akan digunakan oleh siswa dalam proses pembelajaran membaca. Pada cover depan di buatkan judul e-modul, kelas, tema, subtema, dan nama penulis. Selain itu, pada cover juga ditampilkan gambar yang berkaitan dengan suhu dan kalor serta gambar siswa SD yang menarik untuk dijadikan cover e-modul sehingga siswa tertarik untuk membaca emodul yang disediakan.

Selain cover depan, pada e-modul ini juga terdapat cover belakang yang menjadi sampul penutup dari e-modul yang dirancang. Pada cover belakang hanya disajikan gambar yang berkaitan dengan suhu dan kalor, serta gambar kartun siswa SD yang merasa senang telah berhasil menghidupkan api unggun untuk kegiatan perkemahannya. Api unggun merupakan salah satu contoh suhu dan kalor dalam kehidupan sehari-hari siswa. Berikut gambaran cover depan dan belakang e-modul membaca berbasis Higher Order Thinking Skills (HOTS).

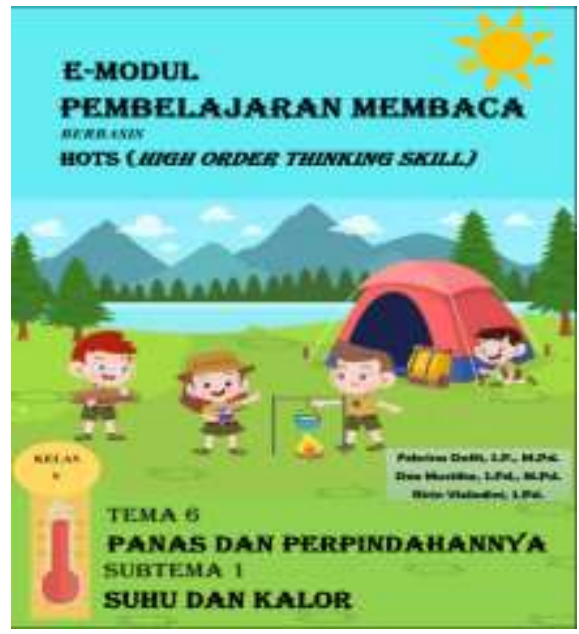

Gambar 1. Sampul depan

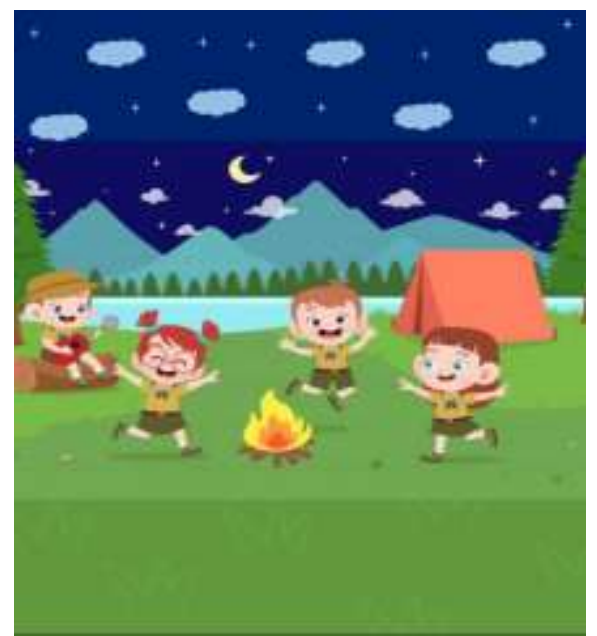

Gambar 2. Sampul belakang

\section{b. Kata pengantar}

Kata pengantar berisi tujuan e-modul dan ucapan terimakasi atas selesainya e-modul ini, selain itu pada kata pengantar terdapat alasan singkat peneliti dalam membuat e- modul dan manfaat yang bisa diperoleh dengan penggunaan e-modul membaca dalam proses pembelajaran.

\section{c. Tentang e-modul}

Halaman "tentang e-modul" berisi tentang petunjuk yang dijadikan sebagai arahan dalam penggunaan e-modul. Di dalam halaman ini terdapat ringkasan singkat bagian-bagian isi pembelajaran. Pada setiap pembelajaran yang ada pada e-modul akan terdapat pembelajaran, jelajah/host, laboratorium, cakrawala, evaluasi, rangkuman, dan HOTS. Tujuh bagian ini adalah kunci utama dalam perancangan dan pembuatan emodul karena bagian-bagian tersebut adalah bagian isi dari e-modul.. Berikut tampilan tentang e-modul. 
4896 Pengembangan Bahan Ajar Membaca Berbasis Higher Order Thinking Skills pada Siswa Sekolah DasarAulia Diana Devi, Subiyantoro

DOI: https://doi.org/10.31004/edukatif.v3i6.1565

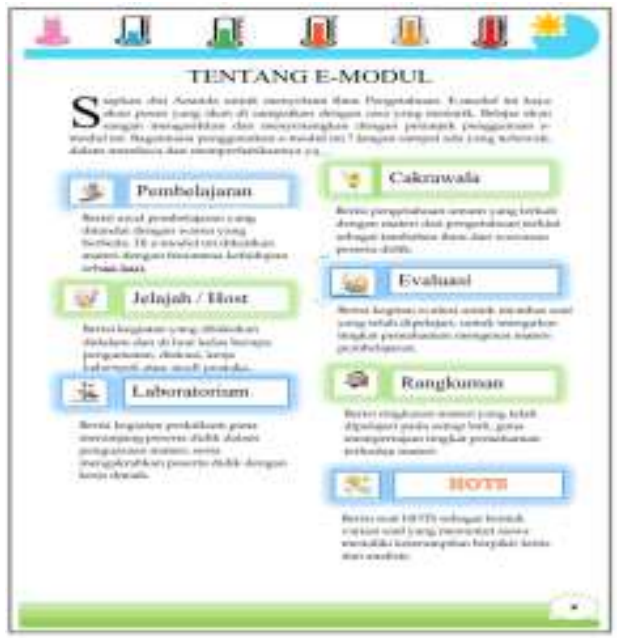

Gambar 3. Tentang e-modul

\section{d. Petunjuk e-modul}

Halaman petunjuk e-modul berisi tentang hal-hal penting yang harus dipahami siswa sebelum menggunakan e-modul membaca dalam proses pembelajaran. Ada lima petunjuk yang dideskripsikan pada bagian ini. Siswa dapat membaca petunjuk e-modul agar dapat menggunakan e-modul dengan baik.

\section{e. Daftar isi}

Daftar isi bertujuan menginformasikan kepada siswa atau pembaca apa saja topik yang ditampilkan dalam e-modul membaca sehingga siswa dengan mudah melacak materi yang ingin dibaca tanpa harus membolak balikan halaman demi halaman satu persatu. Jadi saat siswa menggunakan e- modul membaca berbasis Higher Order Thinking Skills dapat dilihat dari daftar isi.

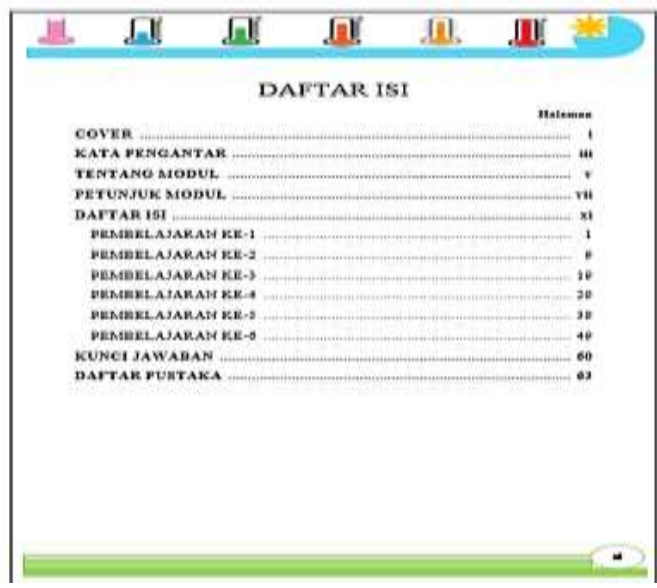

Gambar 4. Daftar isi e-modul

\section{f. Pembelajaran}

Pembelajaran merupakan bagian isi dari e-modul membaca dan merupakan bagian terpenting di dalam membaca materi pembelajaran modul ini. Pada e-modul membaca terdapat enam pembelajaran yang dimulai dengan pembelajaran ke-1 hingga pembelajaran ke-6. Pada setiap pembelajaran terdapat Kompetensi Dasar, matapelajaran pokok, tujuan pembelajaran, materi, rangkuman, dan evaluasi. Bagian-bagian pembelajaran itu disajikan dengan tujuan membaca pemahaman siswa bertahap dan berproses sehingga mampu memahami akan bacaannya. Selain itu pada pembelajaran juga terdapat cakrawala, jelajah/ host, pratikum, dan HOTS. Pada setiap pembelajaran dirancang tujuan pembelajaran yang ingin dicapai. 
4897 Pengembangan Bahan Ajar Membaca Berbasis Higher Order Thinking Skills pada Siswa Sekolah DasarAulia Diana Devi, Subiyantoro

DOI: https://doi.org/10.31004/edukatif.v3i6.1565

Dalam menentukan tujuan pembelajaran dimulai dengan menyebut Audience atau siswa sehingga untuk terlihat untuk siapa tujuan pembelajaran yang dirancang. Tujuan itu kemudian mencantumkan Behavior atau kemampuan yang harus didapatkan oleh siswa. Selain itu, pada tujuan juga harus ada Condition (kondisi), yaitu seperti apa perilaku atau kemampuan yang akan diperoleh siswa setelah melaksanakan pembelajaran tersebut.

Kegiatan pembelajaran yang dirancang pada e-modul membaca adalah untuk memberikan memberikan pemahaman kepada siswa bahwa membaca itu adalah sebuah proses untuk memahami bacaan akan teks yang ada, memberikan pengalaman belajar yang melibatkan proses mental dan fisik melalui interaksi antara siswa dengan siswa, siswa dengan guru, siswa dengan lingkungan, dan siswa dengan sumber belajar dalam rangka mencapai Kompetensi Dasar (KD).

Pada setiap pembelajaran disajikan rangkuman materi, tujuannya adalah siswa memahami materimateri yang telah mereka pelajari, jadi tidak hanya sekedar membaca teks, tetapi membaca teks yang dipandu untuk mempelajari materi pembelajaran.

Pada akhir pembelajaran, dirancang sebuah evaluasi. Evalusi pembelajaran merupakan proses pengumpulan dan pengolahan informasi untuk mengukur pencapaian hasil belajar siswa. Evaluasi yang diberikan mengandung soal-soal berbasis Higher Order Thinking Skills (HOTS), karena memang tujuan dari e-modul ini adalah melatih kemampuan berpikir tingkat tinggi siswa SD setelah membaca e-modul. Selain pada evaluasi, soal HOTS juga terdapat pada proses kegiatan membaca yang dilakukan oleh siswa. Soal HOTS yang diberikan memliki kode tersendiri, yaitu adanya bintang 2 yang membedakannya dengan soal yang belum berbasis HOTS. Tampilan terkait pembelajaran dalam e-modul membaca sebagai berikut:
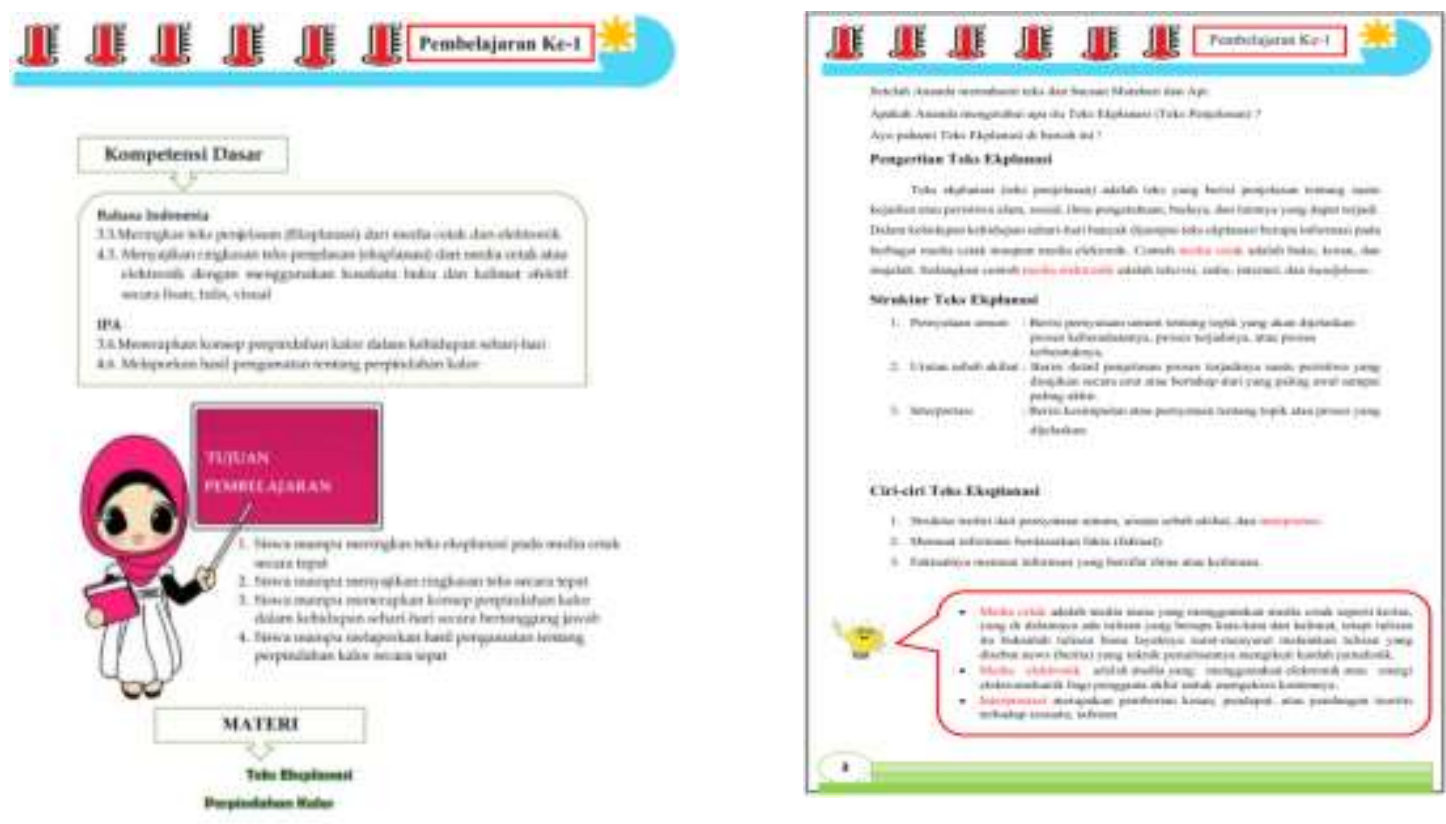

Gambar 5. Uraian Materi pembelajaran ke-1 
4898 Pengembangan Bahan Ajar Membaca Berbasis Higher Order Thinking Skills pada Siswa Sekolah DasarAulia Diana Devi, Subiyantoro

DOI: https://doi.org/10.31004/edukatif.v3i6.1565

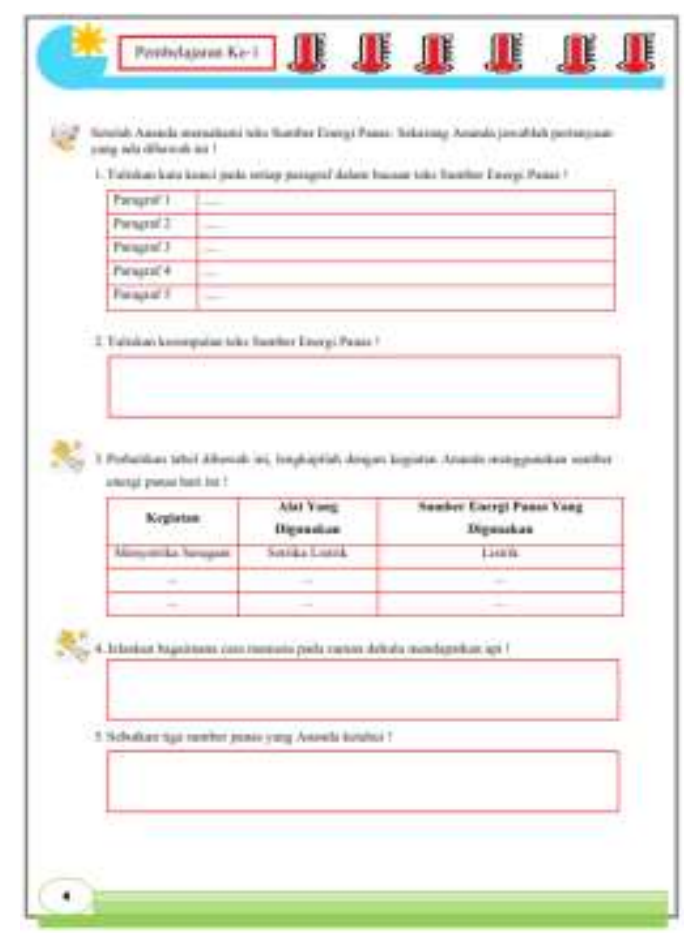

Gambar 6 Jelajah dan HOTS pembelajaran ke-1

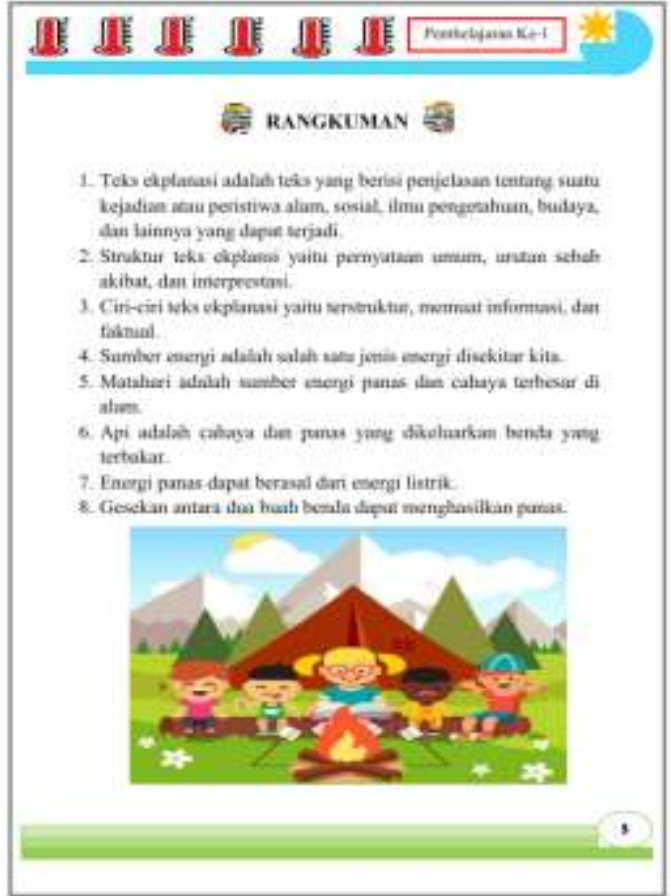

Gambar 7. Rangkuman Pembelajaran ke-1

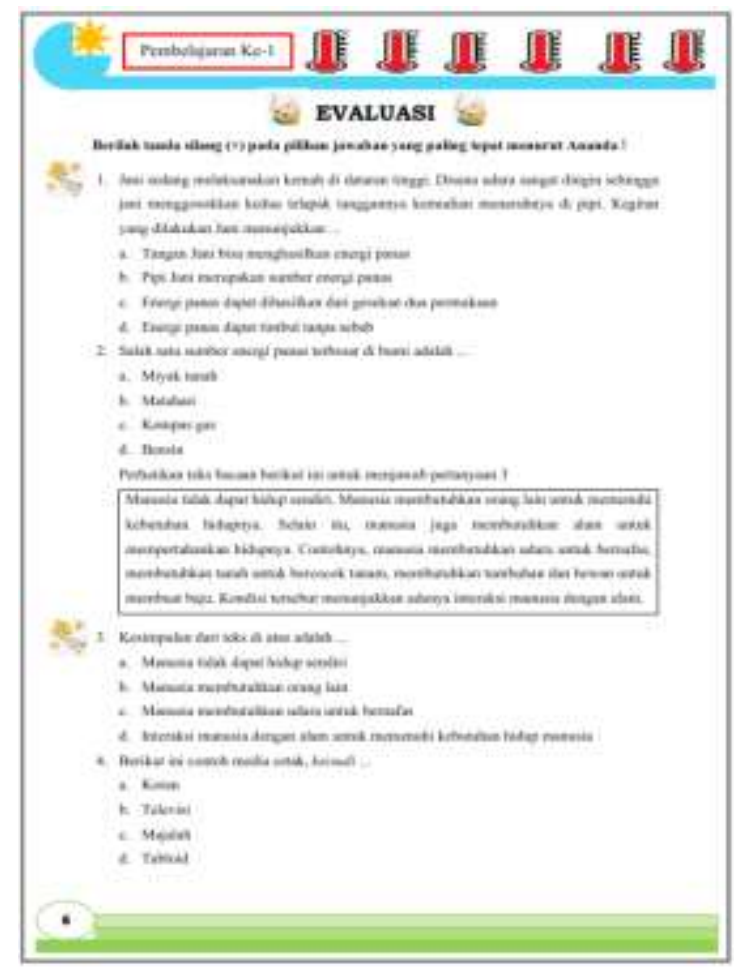

Gambar 8. Evaluasi pembelajaran ke-1 
4899 Pengembangan Bahan Ajar Membaca Berbasis Higher Order Thinking Skills pada Siswa Sekolah DasarAulia Diana Devi, Subiyantoro

DOI: https://doi.org/10.31004/edukatif.v3i6.1565

\section{g. Kunci Jawaban}

Kunci jawaban terletak setelah evaluasi pembelajaran ke-6. Tujuan pembuatan kunci jawaban adalah untuk mengetahui kebenaran jawaban dari pertanyaan yang dijawab siswa. Berikut ini contoh tampilan kunci jawaban:

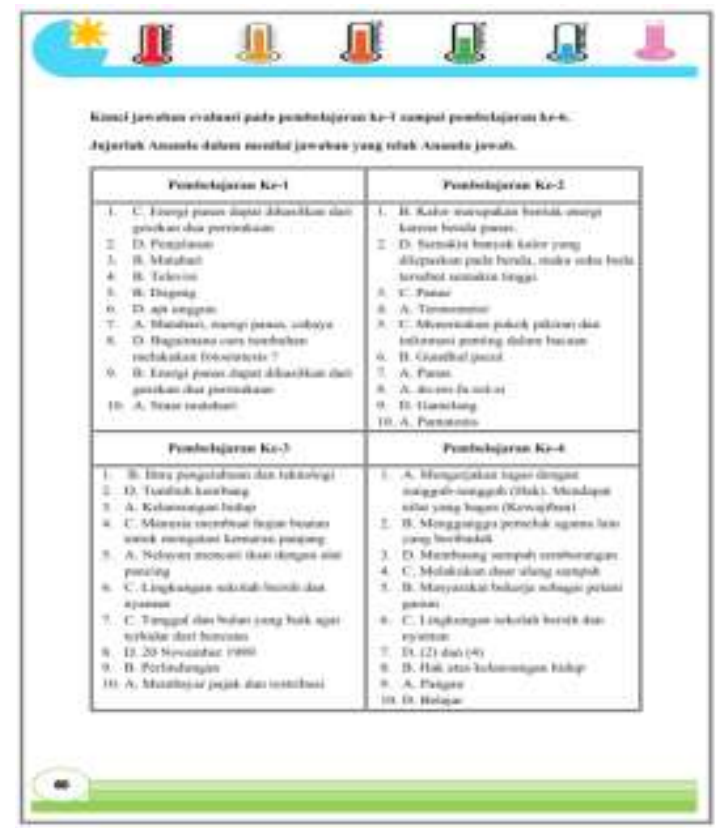

Gambar 9. Kunci Jawaban

\section{Tahap Develop (Pengembangan)}

Tahap pengembangan bertujuan untuk menghasilkan e-modul membaca berbasis HOTS yang valid, praktis, dan efektif sehingga layak digunakan dalam proses pembelajaran. Tahap pengembangan dilakukan dengan cara validasi oleh validator. Peneliti meminta penilaian dari dua orang validator desain, dua orang validator materi, dan dua orang validator Bahasa. Masing-masing penilaian dilakukan oleh validator ahli dan validator praktisi supaya mendapatkan hasil yang seimbang antara ahli dan praktisi. Nama-nama validator modul membaca berbasis HOTS adalah sebagai berikut:

\section{a. Validasi Desain}

Validasi desain dilakukan oleh validator ahli dan validator praktisi. Tujuan validasi desain adalah untuk melihat kelayakan tampilan, penggunaan huruf, kriteria fisik, dan kemudahan penggunaan e-modul. Setelah mendapatkan saran dari validator, maka peneliti memperbaiki modul sesuai yang disarankan. Proses validasi menggunakan angket yang berkaitan dengan desain e-modul membaca. Hasil validasi yang diberikan validator kemudian peneliti persentasekan untuk bisa menentukan kriteria kelayakan desain e-modul Berdasarkan penilaian validator ahli di atas, terlihat bahwa sebelum revisi rata-rata persentase penilaian desain modul adalah $85,83 \%$ artinya desain e- modul membaca memiliki kriteria "sangat layak", dengan kualifikasi sangat tinggi dan tinggi. Kemudian, desain modul direvisi sesuai arahan validator dan dilakukan validasi kembali untuk mendapatkan persentase kelayakan yang lebih baik lagi. Hal ini terbukti dengan naiknya persentase validasi desain oleh validator ahli setelah di revisi, yaitu 97,75\%. Artinya desain e-modul membaca menurut validator ahli memiliki kriteria "sangat layak" dengan kualifikasi sangat tinggi dan tinggi.

Persentase penilaian yang diberikan validator praktisi sebelum revisi adalah sebesar 89,55\% artinya emodul membaca ini sangat layak digunakan, akan tetapi untuk mendapatkan persentase yang lebih baik lagi maka peneliti revisi kembali desain e-modul serta validasi ulang. Persentase hasil validasi desain e-modul 
4900 Pengembangan Bahan Ajar Membaca Berbasis Higher Order Thinking Skills pada Siswa Sekolah DasarAulia Diana Devi, Subiyantoro

DOI: https://doi.org/10.31004/edukatif.v3i6.1565

membaca setelah revisi oleh validator praktisi adalah 96,23\% sehingga dapat disimpulkan bahwa desain pada bahan ajar e-modul berbasis HOTS memiliki kriteria "Sangat Layak" dengan kualifikasi sangat tinggi dan tinggi. Adapun tampilan cover e-modul membaca berbasis HOTS sebelum dan sesudah melakukan revisi dengan validator desain adalah sebagai berikut, adapun tampilan cover e-modul membaca berbasis HOTS sebelum dan sesudah melakukan revisi dengan validator desain adalah sebagai berikut:

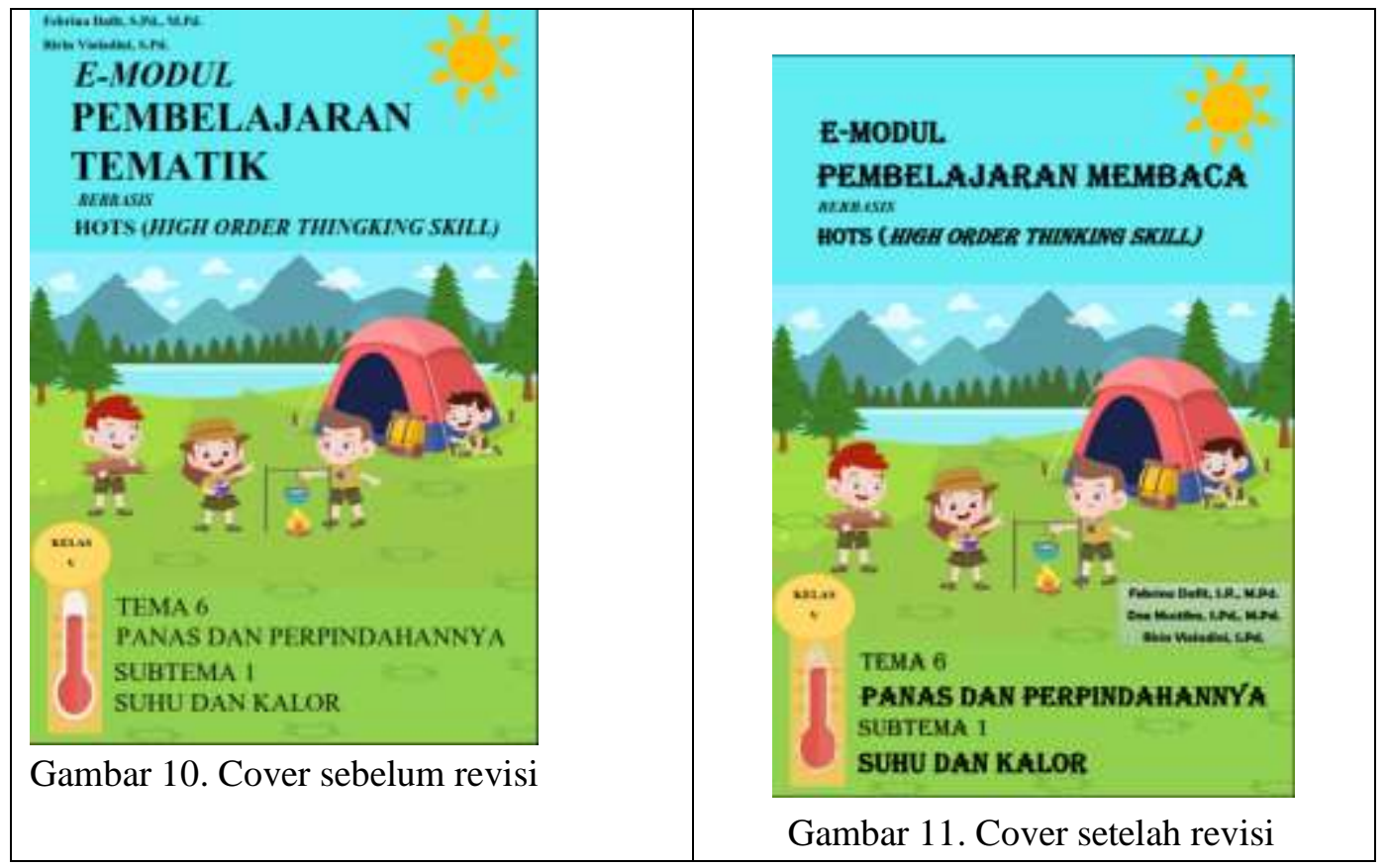

\section{b. Validasi Materi}

Validasi materi dilakukan untuk melihat kesesuaian materi yang digunakan peneliti, ketepatan dan kejelasan materi, dan evaluasi atau penggunaan soal pada e-modul berbasis HOTS. Berdasarkan saran validator materi, baik validator ahli maupun validator praktisi maka peneliti melakukan revisi e- modul membaca berbasis HOTS sesuai dengan arahan. Revisi yang dilakukan kemudian dilakukan validasi kembali untuk mendapatkan e-modul yang layak digunakan. Berikut tampilan revisi materi yang peneliti lakukan pada bagian awal setiap pembelajaran, yaitu menampilkan Kompetensi Dasar, tujuan pembelajaran, dan materi pokok dari pembelajaran yang ada. Tujuannya untuk membuat bahan bacaan yang berkaitan dengan materi yang telah dianalisis sebelumnya.

Selain memberikan saran, selama proses validasi materi validator juga memberikan hasil validasi pada aspek-aspek penilain. Aspek-aspek tersebut peneliti persentasekan sehingga bisa melihat kriteria materi e-modul membaca. Berikut hasil persentase validasi materi e-modul membaca berbasis HOTS oleh validator ahli. Berdasarkan tabel 4.8 persentase penilaian validasi materi dengan validator ahli memperoleh nilai ratarata 93,1\% artinya kriteria kelayakan materi e-modul membaca adalah sangat layak dengan kualifikasi sangat tinggi dan tinggi. Meskipun materi e-modul membaca berbasis HOTS sudah berkriteria sangat layak, peneliti tetap melakukan validasi setelah adanya saran dari validator. Persentase hasil validasi setelah revisi adalah 98,3\% artinya materi e-modul membaca sudah sangat kayak untuk digunakan.

Selain validasi materi oleh validator ahli, e-modul ini juga divalidasi oleh validator praktisi. Tujuannya untuk melihat hasil penilaian materi menurut guru atau praktisi, karena gurulah yang lebih mengerti bagaimana praktik materi yang sebenarnya di SD. Berikut hasil validasi materi oleh validator praktisi.

Penilaian validasi materi dengan validator praktisi memperoleh hasil persentase nilai rata-rata sebesar $85,7 \%$ sehingga dilihat dari kriteria kelayakan yaitu "Sangat Layak" dengan kualifikasi sangat tinggi dan 
4901 Pengembangan Bahan Ajar Membaca Berbasis Higher Order Thinking Skills pada Siswa Sekolah DasarAulia Diana Devi, Subiyantoro

DOI: https://doi.org/10.31004/edukatif.v3i6.1565

tinggi, maka perlu dilakukan revisi perbaikan yang berikaitan dengan saran yang diberikan validator. Sedangkan rata-rata persentase penilaian validasi materi setelah dilakukan revisi adalah

$95,1 \%$, artinya materi e-modul membaca berbasis HOTS sangat layak dan berada pada kualifikasi sangat tinggi. Dengan begitu, materi e-modul membaca berbasis HOTS untuk siswa SD sangat layak untuk digunakan.

\section{c. Validasi Bahasa}

Validasi Bahasa berkaitan dengan Pedoman Umum Ejaan Bahasa Indonesia (PUEBI) dalam ejaannya yang telah disempurnakan pada produk yang di kembangkan. Validasi Bahasa dilakukan oleh validator ahli dan validator praktisi yang menilai kelugasan, interaktif, kesesuaian bahan bacaan dengan kaidah Bahasa, serta penggunaan istilah, simbol, dan icon dari e-modul yang dikembangkan. Saran-saran yang diberikan validator Bahasa untuk kesempurnaan Bahasa e-modul pembelajaran membaca berbasis HOTS adalaBahasa e-modul pembelajaran membaca berbasis HOTS diperbaiki sesuai saran dari validator ahli dan validator praktisi. Berikut ini contoh hasil revisi. Berdasarkan tabel 4.11 terlihat bahwa rata-rata persentase validasi Bahasa oleh validator ahli sebelum revisi adalah $81 \%$, artinya Bahasa yang digunakan pada e-modul memiliki kriteria sangat layak dengan kualifikasi sangat tinggi dan tinggi. Meskipun sudah kriteria sangat layak, Bahasa e-modul tetap diperbaiki sesuai saran validator. Rerata persentase validasi Bahasa oleh validator ahli setelah revisi adalah 95\%, maka disimpulkan bahwa Bahasa e-modul pembelajaran membaca berbasis HOTS menurut validator ahli sudah sangat layak untuk digunakan. Bahasa yang digunakan sudah sesuai dengan karakteristik Bahasa siswa SD dan mudah dipahami oleh siswa SD. Kalimatkalimat yang digunakan dalam e- modul mendorong siswa untuk dapat berpikir kritis dan kreatif, sehingga siswa kelas V SD terlatih untuk menjawab soal-soal berbasis HOTS. Selain itu penggunaan huruf pada emodul menarik bagi siswa SD, dan itu menjadi daya Tarik di dalam penggunaan e-modul membaca berbasis HOTS. Selain validator ahli, pada validasi Bahasa juga dibutuhkan validator praktisi. Selain melihat respon guru, peneliti juga melihat respon siswa dengan melakukan ujicoba produk yaitu uji coba skala terbatas yang terdiri dari 6 orang siswa diantaranya 3 orang siswa berada di kelas VA dan 3 orang siswa berada di kelas VB. Uji coba terbatas ini digunakan untuk memperoleh dan mengetahui kualitas dari e-modul membaca berbasis HOTS pada Tema 6 "Panas dan Perpindahan" Subtema 1 "Suhu dan Kalor". Respon yang diberikan siswa bertujuan untuk melihat kemenarikan e-modul membaca berbasis HOTS dalam proses pembelajaran.

Berdasarkan tabel 4.15 hasil uji coba lapangan skala terbatas yang melibatkan 6 orang siswa menunjukkan hasil jumlah skor 75 dari skor maksimal pernyataan adalah 78. Selanjutnya diketahui bahwa tanggapan siswa dari uji coba skala terbatas ini diperoleh rata-rata prentase penilaian sebesar 92,5\% dengan kriteria "Sangat Menarik". Hal ini sejalan dengan pendapat siswa pada saat mengikuti uji coba skala kecil, menurut mereka e-modul berbasis HOTS ini menarik jika diterapkan dalam proses pembelajaran. Menurut siswa teks-teks dan gambar yang ada pada e-modul sangat mudah memahami sehingga mereka bisa menjawab soal-soal dengan baik.

\section{SIMPULAN}

Berdasarkan rumusan masalah serta analisis data penelitian dan pembahasan, maka peneliti membuat kesimpulan sebagai berikut, pengembangan e-modul membaca berbasis HOTS ini dikembangkan dengan memperhatian materi pembelajaran, kompetensi dasar (KD) dan tujuan pembelajaran yang sesuai dengan tema 6 "panas dan perpindahan" subtema 1 "Suhu dan Kalor" untuk siswa kelas V Sekolah Dasar. Berdasarkan hasil analisis penilaian e-modul membaca berbasis HOTS oleh validator desain, validator materi, validator bahasa dengan memperoleh skor rata-rata 96,66\% dengan kriteria sangat layak. E-modul 
4902 Pengembangan Bahan Ajar Membaca Berbasis Higher Order Thinking Skills pada Siswa Sekolah DasarAulia Diana Devi, Subiyantoro

DOI: https://doi.org/10.31004/edukatif.v3i6.1565

membaca berbasis HOTS yang dikembangkan memiliki kualitas sangat baik dan layak sehingga dapat dijadikan sebagai alat bantu siswa dalam proses pembelajaran. Sedangkan hasil analisis dari angket respon guru kelas $\mathrm{V}$ terhadap e-modul berbasis HOTS mendapatkan respon positif yang memperoleh rata-rata sebesar 90,5\% yang menunjukkan kategori "Sangat Menarik". Sedangkan analisis dari angket respon siswa terhadap e-modul membaca berbasis HOTS mendapatkan respon positif yang memperoleh rata-rata sebesar 92,5\% yang menunjukkan kategori "Sangat Menarik".

\section{DAFTAR PUSTAKA}

Anggia, V., Ariawan, N., Utami, N. T., Pendidikan, J., Sekolah, G., Dasar, J. P., \& Indonesia, U. P. (2018). Peningkatan Keterampilan Membaca Pemahaman Siswa Sekolah Dasar Melalui Implementasi Model Circ Berbantuan Media Cetak. Al-Aulad: Journal Of Islamic Primary Education, 1(2), 95-104.

Astuti, P. B. (2012). Meningkatkan Kemampuan Membaca Pemahaman Anak Metode Klose. Perspektif Ilmu Pendidikan, 25, 53-61.

Character, O. F., \& Comprehension, E. R. (2012). Model Penilaian Otentik Dalam Pembelajaran Membaca Pemahaman Beroreintasi Pendidikan Karakter. Jurnal Pendidikan Karakter, O(2), 164-178. Https://Doi.Org/10.21831/Jpk.V0i2.1301

Elvina. (2018). Peningkatan Aktivitas Dan Proses Keterampilan Membaca Intensif Dengan Strategi Preview, Question, Read, Self-Recitation, Test (Pqrst). Jurnal Ilmiah Pendidikan Dasar, III, 34-47.

Hanafi. (2017). Konsep Penelitian R \& D Dalam Bidang Pendidikan. Saintifika Islamica: Jurnal Kajian Keislaman, 4(1989), 129-150.

Irdawati; Yunidar; Dan Darmawan. (2017). Meningkatkan Kemampuan Membaca Permulaan Dengan Menggunakan Media Gambar Kelas 1 Di Min Buol, ISSN 2354-614X. Jurnal Kreatif Tadulako Online, 5(4), 1-14. Http://Jurnal.Untad.Ac.Id/Jurnal/Index.Php/JKTO/Article/View/2918

Laili, I., Ganefri, \& Usmeldi. (2019). Efektivitas Pengembangan E-Modul Project Based Learning Pada Mata Pelajaran Instalasi. Jurnal Imiah Pendidikan Dan Pembelajaran, 3(3), 306-315. Https://Ejournal.Undiksha.Ac.Id/Index.Php/JIPP/Article/Download/21840/13513

Listiawan, T. (2016). Pengembangan Learning Management System (Lms) Di Program Studi Pendidikan Matematika Stkip Pgri Tulungagung. Jurnal Ilmiah Pendidikan Informatika, 1(1), 14-22.

Pane, A., \& Darwis Dasopang, M. (2017). Belajar Dan Pembelajaran. FITRAH:Jurnal Kajian Ilmu-Ilmu Keislaman, 3(2), 333. Https://Doi.Org/10.24952/Fitrah.V3i2.945

Purnama, S. (2016). Metode Penelitian Dan Pengembangan (Pengenalan Untuk Mengembangkan Produk Pembelajaran Bahasa Arab). LITERASI (Jurnal Ilmu Pendidikan), 4(1), 19. Https://Doi.Org/10.21927/Literasi.2013.4(1).19-32

Qondias, D., Anu, E. L., Niftalia, I., Pendidikan, S., \& Sekolah, G. (2016). Pengembangan Media Pembelajaran Tematik Berbasis Mind Maping Sd Kabupaten Ngada Flores. Jurnal Pendidikan Indonesia |, 5(2), 176-182.

Rahman, Y., \& Atjalau, C. (2019). [ Cultivation Of Critical Literacy ]. Jurnal Pendidikan, 8(2), 321-332. Https://Doi.Org/10.21070/Pedagogia.V8i2.2430

Retnoasih, N. (2018). Implementasi Pembelajaran HOTS (Higher Order Thinking Skill) IPA Menggunakan Alat Sederhana. Jurnal Penelitian Pendidikan Matematika Dan Sains (JPPMS), 2(2), 48-53.

Saonah, S. (2018). Meningkatkan Kemampuan Membaca Dan Menulis Permulaan Dengan Media Gambar Di Kelas I SD Negeri 222 Pasir Pogor. Jurnal Elementaria Edukasia, 1(1), 101-107.

Sekarini, A. P. (2020). Analisis Penerapan Model Problem Based Learning Berbantuan Mind Mapping Dalam Pembelajaran Gerak Dan Gaya Untuk Meningkatkan Keterampilan Abad Ke-21. Skripsi. P. 
4903 Pengembangan Bahan Ajar Membaca Berbasis Higher Order Thinking Skills pada Siswa Sekolah DasarAulia Diana Devi, Subiyantoro

DOI: https://doi.org/10.31004/edukatif.v3i6.1565

Shobrina, N. Q., Sakti, I., \& Purwanto, A. (2020). Pengembangan Desain Bahan Ajar Fisika Berbasis EModul Pada Materi Momentum. Jurnal Kumparan Fisika, 3(1), 33-40. Https://Doi.Org/10.33369/Jkf.3.1.33-40

Simarmata, Erlan Ariando. Santyadiputra, Gede Saindra \& Divayana, D. G. H. (2017). Pengembangan EModul Berbasis Model Pembelajaran Project Based Learning Pada Mata Pelajaran Pemrograman Grafik Kelas Xii Rekayasa Perangkat Lunak Di Smk Negeri 2 Tabanan. Kumpulan Artikel Mahasiswa $\begin{array}{lllll}\text { Pendidikan Teknik Informatika } & \text { (KARMAPATI), }\end{array}$ Https://Doi.Org/10.23887/Karmapati.V8i2.18632

Sugianto, D., Abdullah, A. G., Elvyanti, S., \& Muladi, Y. (2013). Modul Virtual: Multimedia Flipbook Dasar Teknik Digital. Innovation Of Vocational Technology Education, 9(2), 101-116. Https://Doi.Org/10.17509/Invotec.V9i2.4860

TANIA, L. (2017). Pengembangan Bahan Ajar E-Modul Sebagai Pendukung Pembelajaran Kurikulum 2013 Pada Materi Ayat Jurnal Penyesuaian Perusahaan Jasa Siswa Kelas X Akuntansi Smk Negeri 1 Surabaya. Jurnal Pendidikan Akuntansi (JPAK), 5(2), 1-9.

Tegeh, I. M., \& Kirna, I. M. (2013). Pengembangan Bahan Ajar Metode Penelitian Pendidikan Dengan ADDIE Model. Jurnal $\quad$ IKA, $\quad 11(1), \quad 16$ Https://Ejournal.Undiksha.Ac.Id/Index.Php/IKA/Article/View/1145 